\title{
Burden of Rheumatic Diseases in A Rural Community of Bangladesh
}

MONIRUZZAMAN AHMED, ${ }^{1}$ SYED ATIQUL HAQ ${ }^{2}$ MD. NAZRUL ISLAM, ${ }^{3}$ SREE KRISNA BANIK, ${ }^{4}$ MOHAMMAD NOOR ALAM ${ }^{5}$

\begin{abstract}
Objective: To estimate the magnitude, burden of illness and help-seeking behavior of patients with musculoskeletal complaints and to provide incidence of osteoarthritis, low back pain, fibromyalgia, rheumatoid arthritis, gout, and other inflammatory and non-inflammatory rheumatic diseases in a rural community of Bangladesh.

Methods: The study was conducted in a few villages near Dhaka city which were considered to be a fairly representative sample of Bangladeshi rural population. Data were collected with the help of modified Community Oriented Program for Control of Rheumatic Diseases (COPCORD) questionnaire and a diagnosis using American College of Rheumatology (ACR) criteria was established.

Results: During the 18 months study period, 2685 adults (15 years and above) were included. A total of 44 I $(M=163, F=278)$ developed new musculoskeletal (MSK) pain. The incidence rates were $10.9 / 100$ person-years (PY) for the whole population, 8.2/100 PY for males and I 3.6/l00 PY for females. Nonspecific low back pain (NSLBP), fibromyalgia and osteoarthritis of knee were common MSK problems. A total of 302 patients had complaints of low back pain, of them 204 persons had noninflammatory low back pain; 262 respondents had complaints of knee pain, 38 had satisfied the criteria of knee OA; a total of I 16 respondents suffered from fibromyalgia during the study period. Of the respondents $(M=I 7, F=24) 4 I$ had inflammatory arthropathy. Among the incidences of inflammatory arthritis, rheumatoid arthritis $120(M=101, F=147)$, spondyloarthropathies $150(M=252, F=49)$, ankylosing spondylitis $75(M=|5|, F=0)$, reactive arthritis $50(M=10 I, F=0)$, and psoriatic arthritis $256(M=0, F=49)$ per 100,000 / PY respectively were observed,

Conclusions: Rheumatic diseases are common in the rural community of Bangladesh, affecting nearly a quarter of adult population. Non-specific low back pain (NSLBP), fibromyalgia and osteoarthritis of knee joints are common joint disorders; point prevalence estimates of most common diagnoses were similar to other community surveys using COPCORD methodology.
\end{abstract}

Key words: Epidemiology study, Rheumatic diseases, rural community, Bangladesh.

\section{Introduction:}

Modern trends in the prevalence and effects of rheumatic conditions must be considered in relation to increasing life expectancy and increasing population problems, such as rapid growth of urban populations, new occupational stresses, lifestyle changes and a number of other factors. ${ }^{1}$

COPCORD is an initiative of the World Health Organization (WHO) and International League of Associations of

1. Associate Professor of Medicine, MAG Osmani Medical College, Sylhet

2. Professor \& Head of the Dept. of Rheumatology, Bangabandhu Sheikh Mujib Medical University, Dhaka.

3. Professor of Rheumatology, Bangabandhu Sheikh Mujib Medical University, Dhaka.

4. Professor \& Head of the Dept. of Medicine (Retd.), Bangabandhu Sheikh Mujib Medical University, Dhaka.

5. Associate Professor of Medicine, Chittagong Medical College. Correspondence: Dr. Moniruzzaman Ahmed, Associate Professor of Medicine, MBBS, MD. MAG Osmani Medical College, Sylhet. Abash 11/B, Sylmart Complex, East Zindabazar, Sylhet. Email: dr_zaman01217@yahoo.com Cell No: 01715024714
Rheumatology (ILAR). In 1981 the WHO and ILAR initiated the project ${ }^{2}$ with the primary objective to control rheumatic diseases by both prevention and treatment of pain and disabilities.

The low quality of life in rheumatic diseases induces chronic unquantifiable psychosocial suffering of the patients and their families. ${ }^{3}$ The cost to the United States economy attributed to musculoskeletal disorders is more than 20 billion dollar per annum. ${ }^{4}$

The prevalence of the major rheumatic diseases has been extensively studied in the West for several decades but figures from the third world are only just emerging. ${ }^{5}$

Rheumatic disorders are neglected health problems in Bangladesh and probably no control program has been introduced so far mainly because of lack of necessary information. Communicable diseases were once the main causes of morbidity and mortality but due to the adoption of various public health measures, both at government and non-government levels, the morbidity due to these diseases are now reduced to a great extent. ${ }^{6}$ 


\section{Materials \& Methods:}

The population of Sonargaon Upazila of Narayanganj district was selected for prevalence and incidence study of musculoskeletal diseases in the rural population. This area was selected as being representative of rural population of Bangladesh in respect of socio-demographic characters such as life expectancy, age structures, sex distribution, income, cultures, religion, occupations and social classes. A total population of $2685(\mathrm{M}=1324, \mathrm{~F}=1361)$ of age 15 years and above was interviewed. In this study data were collected with the help of modified COPCORD questionnaire. The questionnaire was translated to Bengali, cross-cultural adaptation and validation were also done. Non-probability sampling method was adopted for the study.

\section{Observations and results:}

\section{Socio-demographic parameters:}

The socio-demographic characters of the sample population are shown in the table 1 . The mean age of sample population was $33.18+15.53$ years. A total of 2685 persons were interviewed. Out of them 163 male and 278 female patients had complaints of new rheumatic problems, 1161 male and 1053 female had no new complaints. Regarding new complaints female preponderance was more than male (Chi square $=23.16, \mathrm{p}<0.001)$, married population of the sample was $72.8 \%$. By occupation, there were $40.9 \%$ housewives, $13.4 \%$ laborers, $10.4 \%$ business, 6.8 service holders and $4.8 \%$ farmers. The distribution of rheumatic complaints by age group and sex are shown in the table 2. The annual incidence of rheumatic complaints increased in middle age group. It was $9.2 \%$ in the age group of 15 to 24 years. In age groups of 35 - 44 years and 45 - 54 years, the rates were $26.3 \%$ and $24.7 \%$ respectively. It was $15.5 \%$ in case of 65 and above age group. There was significant difference in the annual incidence of rheumatic complaints among the middle age group, younger age group and older age group (Chi square 51.48, $\mathrm{p}<0.001$ ) (Fig.-1). More than 20.9 percent of the farmers suffered from rheumatic symptoms, the rate was significantly higher than that of service holders and business professionals (Chi square $=6.58, \mathrm{p}<0.05$ ). By occupation rheumatic disorders were also common in housewives with an annual incidence of $24.4 / 100$ person years. The incidence of rheumatic disorders among laborers was $13.1 / 100$ person years and those of service holders and business professionals were $7.7 / 100$ person years and $12.9 / 100$ person years respectively (Table 3 ). Functional disability in one or more of the common activities was reported by $99.5 \%$ of 440 new positive respondents with the mean duration of 34.44 ( $\mathrm{SD} \pm 33.68$ ) days (Table 5). Regarding functional limitations, the most commonly affected activities were squatting (84.1\%), getting up and down from bed (80.2\%), picking up objects from the floor (78.9\%), getting up and down from vehicle (54.1\%), climbing up and down stairs $(65.7 \%)$ and bathing (65.7\%).

Table - I

Socio-demographic character of study population.

Background characteristics Number Percentage

Age (years)

Mean \pm SD 33.18 \pm 15.53 , Range 15-99

Sex

$\begin{array}{lll}\text { Male } & 1324 & 49.3 \\ \text { Female } & 1361 & 50.7\end{array}$

\section{Occupation}

Agriculture

Labor

Service

Business

House wife

Student

Weavers

No work

Others

\section{Marital status}

Married

Single

582

Widow

Widower

Separated

Divorced

\section{Education}

Primary

581

Secondary +

530

Graduate +

29

Read/sign

398

Illiterate

1147

\section{Economic status}

Upper 37

Middle

$$
771
$$

1877

Lower 128

7

4.8

13.4

6.8

10.4

40.9

6.7

4.1

4.8

8.2

Lower

28.7

69.9 
Table- II

Incidence by age group and sex distribution (Data in the parentheses indicate percentages)

\begin{tabular}{|c|c|c|c|c|c|c|}
\hline \multirow{2}{*}{$\begin{array}{l}\text { Age in } \\
\text { Year }\end{array}$} & \multicolumn{3}{|c|}{ Interviewed population } & \multicolumn{3}{|c|}{ Positive respondent } \\
\hline & Male & Female & Total & Male & Female & Total \\
\hline \multirow[t]{2}{*}{$15-24$} & 456 & 526 & 982 & 32 & 58 & 90 \\
\hline & $(34.4)$ & $(38.6)$ & $(36.6)$ & $(7.0)$ & $(11.0)$ & $(9.2)$ \\
\hline \multirow[t]{2}{*}{$25-34$} & 342 & 291 & 633 & 43 & 60 & 103 \\
\hline & $(25.8)$ & $(21.4)$ & $(23.6)$ & $(12.6)$ & $(20.6)$ & (16.3) \\
\hline \multirow[t]{2}{*}{$35-44$} & 217 & 224 & 441 & 33 & 83 & 116 \\
\hline & (16.4) & $(16.5)$ & $(16.4)$ & $(15.2)$ & $(37.1)$ & $(26.3)$ \\
\hline \multirow[t]{2}{*}{$45-54$} & 137 & 142 & 279 & 29 & 40 & 69 \\
\hline & $(10.3)$ & (10.4) & $(10.4)$ & $(21.2)$ & $(28.2)$ & $(24.7)$ \\
\hline \multirow[t]{2}{*}{$55-65$} & 92 & 103 & 195 & 13 & 26 & 39 \\
\hline & (6.9) & (7.6) & $(7.3)$ & $(14.1)$ & $(25.2)$ & $(20.0)$ \\
\hline \multirow[t]{2}{*}{$65+$} & 80 & 75 & 155 & 13 & 11 & 24 \\
\hline & (6) & $(5.5)$ & $(5.8)$ & (16.3) & (14.7) & (15.5) \\
\hline \multirow[t]{2}{*}{ Total } & 1324 & 1361 & 2685 & 163 & 278 & 441 \\
\hline & (100) & (100) & (100) & & & \\
\hline
\end{tabular}

\section{Table- III}

Incidence by occupation

\begin{tabular}{lccccc}
\hline Occupation & \multicolumn{2}{c}{ Interviewed population } & & \multicolumn{2}{c}{ Positive respondent } \\
\cline { 2 - 3 } \cline { 5 - 6 } \cline { 5 - 6 } & Number & Percent & & Number & Percent \\
\hline Agriculture & 129 & 4.8 & & 27 & 20.9 \\
Labour & 359 & 13.4 & & 47 & 13.1 \\
Service & 182 & 6.8 & & 14 & 7.7 \\
Business & 278 & 10.4 & & 36 & 12.9 \\
House wife & 1098 & 40.9 & & 268 & 24.4 \\
Student & 180 & 6.7 & & 15 & 8.3 \\
Weavers & 109 & 4.1 & & 24 & 22.0 \\
Others & 220 & 8.2 & & 10 & 4.5 \\
No work & 130 & 4.8 & & - & - \\
\hline Total & 2685 & 100.0 & 441 & 16.4 \\
\hline
\end{tabular}

Table-IV

Incidence of rheumatic complaints by site.

\begin{tabular}{lcccc}
\hline Joint and region & $\begin{array}{c}\text { Male } \\
(\mathrm{n}=1324)\end{array}$ & $\begin{array}{c}\text { Female } \\
(\mathrm{n}=1361)\end{array}$ & $\begin{array}{c}\text { Total } \\
(\mathrm{n}=2685)\end{array}$ & \\
\hline & $\%$ & $\%$ & $\%$ & $95 \% \mathrm{CI}$ \\
\hline Spine & 5.7 & 14.2 & 11.0 & $9.88-12.28$ \\
Knee & 6.7 & 12.5 & 9.6 & $8.57-10.85$ \\
Shoulder & 6.7 & 11.5 & 9.2 & $8.11-10.33$ \\
Neck & 4.2 & 8.0 & 9.0 & $7.97-10.18$ \\
Elbow & 4.3 & 8.0 & 6.2 & $5.34-7.18$ \\
Ankle & 4.8 & 7.0 & 5.9 & $5.04-6.86$ \\
Hip & 2.9 & 6.0 & 4.5 & $3.77-5.38$ \\
Wrist & 3.5 & 6.4 & 5.0 & $4.18-5.86$ \\
Hand & 2.4 & 4.7 & 3.6 & $2.92-4.37$ \\
Foot & 2.7 & 4.6 & 3.7 & $3.02-4.49$ \\
Others & 1.1 & .6 & 0.8 & $0.53-1.26$ \\
\hline
\end{tabular}

Table-V

Incidence of rheumatic disorders per 100 person years of observation

\begin{tabular}{lcccc}
\hline Sex & $\begin{array}{c}\text { Population } \\
\text { interviewed }\end{array}$ & $\begin{array}{c}\text { Positive } \\
\text { respondent }\end{array}$ & $\begin{array}{c}\text { Incidence } \\
\text { rate (\%) }\end{array}$ & 95\% CI \\
\hline Male & 1324 & 163 & 12.3 & $10.61-14.23$ \\
Female & 1361 & 278 & 20.4 & $18.33-22.69$ \\
\hline Total & 2685 & 441 & 16.4 & $15.05-17.89$ \\
\hline
\end{tabular}

Table-V

Incidence of rheumatic diseases per 100 person years of observation (Data in parentheses indicate incidence per 100 person years)

\begin{tabular}{lcccc}
\hline $\begin{array}{l}\text { Name of the } \\
\text { diseases }\end{array}$ & $\begin{array}{c}\text { Male } \\
\mathrm{n}=1324\end{array}$ & $\begin{array}{c}\text { Female } \\
\mathrm{n}=1361\end{array}$ & $\begin{array}{c}\text { Total } \\
\mathrm{n}=2685\end{array}$ & $95 \%$ CI \\
\hline Low back pain & $51(3.85)$ & $113(8.53)$ & $164(6.11)$ & $5.25-7.10$ \\
Fibromyalgia & $42(3.17)$ & $74(5.59)$ & $116(4.32)$ & $3.60-5.18$ \\
Osteoarthritis of knee & $16(1.2)$ & $22(1.66)$ & $38(1.42)$ & $1.02-1.96$ \\
Cervical spondylosis & $14(1.06)$ & $16(1.21)$ & $30(1.12)$ & $0.77-1.61$ \\
Lumbar spondylosis & $17(1.28)$ & $19(1.43)$ & $36(1.34)$ & $0.95-1.87$ \\
Myofascial pain & $5(0.37)$ & $7(0.52)$ & $12(0.45)$ & $0.27-0.85$ \\
syndrome & & & & \\
Frozen shoulder & $4(0.30)$ & $9(0.68)$ & $13(0.48)$ & $0.44-1.13$ \\
Polyarthralgia & $5(0.38)$ & $14(1.06)$ & $19(0.71)$ & $0.44-1.13$ \\
Rheumatoid arthritis & $4(0.30)$ & $9(0.68)$ & $13(0.48)$ & $0.27-0.85$ \\
Ankylosing & $8(0.60)$ & $1(0.07)$ & $9(0.34)$ & $0.16-0.66$ \\
spondylitis & & & & \\
Prolapsed disc & $2(0.15)$ & $2(0.15)$ & $4(0.15)$ & $0.05-0.41$ \\
No abnormality & $1(0.07)$ & $1(0.07)$ & $2(0.07)$ & $0.01-0.30$ \\
Psoriatic arthritis & - & $1(0.08)$ & $1(0.04)$ & $0.01-0.24$ \\
Others & $49(3.70)$ & $94(6.93)$ & $143(5.3)$ & $4.52-6.26$ \\
\hline
\end{tabular}




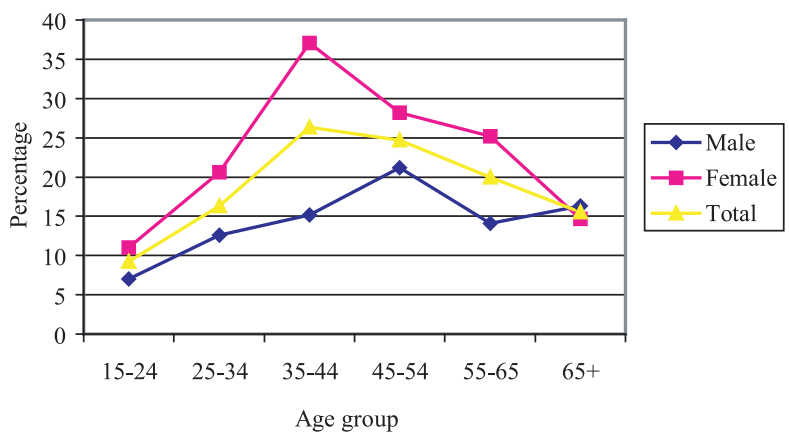

Fig.-1: Incidence of rheumatic diseases by age group and sex

\section{Results of the examination phase:}

The total incidence of rheumatic diseases was $16.4 / 100$ person years of observation ( $95 \%$ CI 15.05-17.89) of the adult population aged 15 years and above (Table-V) and in male it was 12.3 / 100 person years of observation (95\% CI 10.6114.23) and in female 20.4/ 100 person years of observation (95\% CI 18.33-22.69).

NSLBP (Table-VI) was the most common rheumatic disease and its incidence was 6.11/100 person years of observation (95\% CI 5.25-7.10). Female suffered more often than the male (Chi-square test $=20.53, \mathrm{p}<0.001$ ).

Fibromyalgia was the second most common rheumatic disease followed by osteoarthritis of knee. The incidence of fibromyalgia was $4.32 / 100$ person years of observation $(95 \%$ CI 3.60-5.18). Female was more affected than male (Chi-square test, $30.88 \mathrm{p}<0.001)$.

Osteoarthritis of knee appeared in 1.42\% (95\% CI1.02-1.96). Both sexes were equally affected. The incidence of rheumatoid arthritis was $0.48 / 100$ person years of observation $(95 \% \mathrm{CI}$ $0.27-0.85)$. Nine female and four male were diagnosed as rheumatoid arthritis.

Soft tissue rheumatism was present in $5.3 \%$ of population and this included all cases of epicondylitis, tendinitis, bursitis and tenosynovitis. Frozen shoulder was present in $0.48 \%$ of the population and it was more common in female.

Among the rheumatic patients, $21.5 \%$ had the history of loss of work for their disability due to musculoskeletal problems. The mean duration of work loss due to disability was $7.71 \pm 14.59$ days in the preceding months.

\section{Discussion:}

The present study is the first of its kind in Bangladesh in a defined rural population for the estimation of prevailing new cases of rheumatic morbidity in eighteen-month period. The response rate was as high as in other COPCORD studies.
Burden of Rheumatic Diseases in A Rural Community of Bangladesh

Out of 2685 persons, 441 (male-163, female-278) had new rheumatic complaints during this period. Overall incidence of rheumatic diseases was $16.4 / 100$ person years of observation (95\% CI 15.05-17.89). Female suffered significantly more than the male $(\mathrm{p}<0.001)$. An attempt was made to identify the associations between occurrence of rheumatological morbidities and variables like sociodemographic factors such as life expectancy, age structures, sex distribution, income, culture, religions, occupations and social classes. Common as well as uncommon rheumatic disorders were also identified. Data collection by trained interviewer was satisfactory in that data of modest sophistication were collected from a large population. The low cost approach had been shown to be suitable for the study in developing countries. ${ }^{7}$ Nonspecific low back pain was the most common disorder and its incidence was 6.11/ 100 person years $(95 \%$ CI $5.25-7.10)$ followed by fibromyalgia, $4.32 / 100$ person years (95\% CI 3.60-5.18). A female preponderance was observed in almost all rheumatic disorders. The differences of incidence between male and female were significant, in cases of low back pain (male-51 vs. female-113, ) and fibromyalgia (male-42 vs. female-116). Four men and nine women were diagnosed as rheumatoid arthritis with an incidence of $0.48 / 100$ person years of observation (95\% CI $0.27-0.85)$. Peoples of both sexes equally complained of their disabilities and functional limitations in one or more of the daily activities (male- $100 \%$ vs. female$99 \%$ ) and $22 \%$ had the history of loss of work for a mean duration of 7.71days. As in most of the COPCORD studies, the low back pain ranked first among the individual pain sites with an incidence of $6.11 / 100$ person years, it was $3.85 \%$ in male and $8.53 \%$ in female; the common posture in local culture is squatting both in domestic and work related activities, this finding contradicts Farhni's suggestion that squatting protected villagers in India who were said not to have back pain. Another remarkable finding in our study was a high incidence of fibromyalgia with an incidence of $4.32 / 100$ person years, female suffered more than male. The high prevalence rates for fibromyalgia were also reported in USA $3.4 \%$ in women, $0.5 \%$ in men ${ }^{8}$ in Pakistan $(2.01 \%)^{5}$, and Norway with an annual incidence of $5.8 \%$ among women of 26-51 years. ${ }^{9}$ Osteoarthritis was a common arthritis in all COPCORD studies. The incidence of osteoarthritis of knee was $1.42 / 100$ person years with almost equal preponderance in both sexes. In COPCORD surveys, the prevalence of osteoarthritis of knee was $5.1 \%{ }^{10}$ in Indonesia, $3 \%$ in Filipino rural community, ${ }^{11} 5.8 \%$ in rural area of India ${ }^{12}$ and $3.7 \%$ in Pakistan. ${ }^{5}$ The total annual incidence rates of osteoarthritis of knees were 28.7/100,000 person years of observation in Norway, ${ }^{13} 0.15$ to $0.36 / 1000$ in Greece, $,{ }^{14} 39 / 100,000$ of the 
population of 16 years and above age in Finland, ${ }^{15} 22$ per 100,000 in man and 60 per 100,000 in woman in $\mathrm{USA}^{16}$ in patients aged 18 or older.

In a Mexico study the most common sites of involvement were knee $(12.3 \%)$; low back $(6.3 \%)$; ankles $(6 \%)$ and shoulders $(5.3 \%) .{ }^{17}$ In our study $67.6 \%$ patients of osteoarthritis of knees had BMI 18.5-24.99, 24.3\% had less than 18.5 and $5.4 \%$ were overweight or obese. In the villages where malnutrition and poverty are very frequent, obesity should not be expected at a high rate. Other physical factors such as weight bearing, carrying loads that cause injury to the knee may be responsible for osteoarthritis of knee.

The incidence of rheumatoid arthritis was $0.48 \% / 100$ person years with distinct female preponderance. The prevalence of rheumatoid arthritis in the developing countries has been ascribed to non-recognition of mild diseases, demographic variables such as reduced survival of women with and without RA, or the absence of environmental causative factors. ${ }^{5}$ Wolfe ${ }^{18}$ had a review from 14 studies, mainly from developed countries, according to the criteria of definite $\mathrm{RA}$, the prevalence rate of 0.3 to $1.5 \%$ was found, with an overall figure of about $1 \%$; a WHO-ILAR-COPCORD study of rheumatic diseases in rural area of India the prevalence was $0.68 \%,{ }^{13}$ and in the rural area of Philippine it was $0.2 \% .{ }^{19}$ Similarly the frequency of ankylosing spondylitis was at a low rate with an annual incidence of $0.34 \%$ almost identical to the findings of other COPCORD studies probably justifying the statement that inflammatory arthritis does not appear to be a common problem in the population of developing countries. The incidence of soft tissue rheumatism was 5.3\%; it included all cases of epicondylitis, tendinitis, bursitis, tenosynovitis and myofascial pain syndrome. The higher prevalence among the illiterate people may be related to their earlier engagement in physical work.

The prevalence of gout in the Filipino rural area was $0.6 \%$, Wigley et al and Chopra ET al ${ }^{19,12}$ have shown that $0.12 \%$ of rural population of India suffered from gout and no case was identified in rural area of northern Pakistan, ${ }^{5}$ in this study no case of gout was identified.

The functional limitations in one or more of the common daily activities were found in $99.5 \%$ of the positive respondents. Squatting (84\%), getting up and down from bed $(80 \%)$ and bending or picking up objects $((79 \%)$ from the floor were commonly affected activities.

The point prevalence of NSLBP was 16.0\% (95\% CI-14.63$17.51)$ with female predominance $(22.6 \% \mathrm{v} 9.7 \%)$. The prevalence of NSLBP increased in middle age group, it was highest in the 35-44 age group both for men (17.3\%) and women $(27 \%)$. In the developed countries prevalence of low back pain in the adult population is estimated at $14-31 \%$ with a $60-80 \%$ lifetime incidence. ${ }^{20}$ In our study chronic low back pain occurred significantly and more frequently in the illiterate population, which was $21.1 \%$, it was common in the housewives with a prevalence of $24.7 \%$. In the work related activities, 23 percent of the farmers suffered from chronic low back pain, the rate were significantly higher than that of service holders and business professionals.

The definition of burden of disease includes a measure of function and health related quality of life (HRQOL) that is weighted by disease prevalence and rheumatic diseases as a group can be ranked alongside neurological, cardiac, or pulmonary conditions as a major disease. ${ }^{21}$ The total economic burden of rheumatic diseases is often more substantial than other chronic conditions, including cardiovascular diseases and cancer; and the impact of the disability caused by musculoskeletal diseases is significant on both direct (long-term care in osteoporosis for example) and indirect costs like productivity loss in chronic patients. ${ }^{22}$ The current study exposes a considerable burden of rheumatic diseases in the rural population of Bangladesh necessitating increased demand for awareness of the gravity of the prevailing situation, measures for prevention and control of problems in this regard. Mechanical and degenerative diseases are the main causes of morbidity, disability and work loss. Future studies should aim at identification of occupational and ergonomic risk factors of chronic low back pain; such studies should ideally include larger samples. Intervention studies should be designed to assess the effectiveness of modification of physical and environmental risk determinants for reducing low back pain morbidity.

\section{Conflict of Interest: None}

\section{References:}

1. Muirden KD. Epidemology and community studies: Asia / Pacific region. Bailliere's Clin Rheumatol 1995; 9(1): 11-20.

2. Muirden KD. The developing relationship between the world Health Organisation and the International league against rheumatism. J Rheumatol 1991; 18(6): 793-95.

3. Darmwan J, Epidemiology of the rheumatic diseases in the Asia-Pacific region. APLAR Journal of rheumatology 1997; 1: $124-28$.

4. Nuki G, Ralston SH and Luqmani R. Diseases of the connective tissues, Joints and bones. In: Haslett C, Chilvers ER, Hunter JAA, Boon NA editors. Davidson's Principles and practice of Medicine, $18^{\text {th }}$ ed. Churchill Living stone, Edinburgh 1999: 801-76. 
5. Farooqi and Gibson T. Prevalence of the major rheumatic disorders in the adult population of north Pakistan. Br J Rheumatol 1998; 37: 491-95.

6. Akbar MS, Ehsan A, and Haider ACM. Clinical profile and management of acute respiratory infections in Dhaka Shishu Hospital. Bang J child health 1992; 16: 5-8.

7. Manhan L, Caragay R, Muirden KD, Allander E, Valkenberg Ha, Wigley RD. Rheumatic pain in Philipine village. Rheumatol Int 1985; 5:149-53.

8. Gilliland BC. Relapsing polychondritis and other arthritides. In: Fauci AS, Braunwald E, Isselbacher KJ,Wilson JD, Martin JB, Kasper DL et al. editors. Harrison's principles of internal medicine. $14^{\text {th }}$ ed. Mc Graw-Hill, USA 1998: 1951-63.

9. Forseth KO, Gran JT, Husby G. A Population study of the incidence of fibromyalgia among women aged 26-55 yr. Br J Rheumatol 1997; 36(12): 1318-23.

10. Darmawan J, Valkenberg HA, Muirden KD and Wigley RD. Epidemiology of rheumatic disease in rural and urban Indonesia: a WHO-ILAR-COPCORD study, Stage-I, phase2. Ann Rheum Dis 1991; 51: 525-8.

11. Manhan L, Caragay R, Muirden KD, Allander E, Valkenberg Ha, Wigley RD. Rheumatic pain in Philipine village. Rheumatol Int 1985; 5: 149-53.

12. Chopra A, Patil J, Billampelly V, Relwani J, Tandle HS. The Bhigwan (INDIA) COPCORD: Methodology \& First information Report: APLAR Journal of Rheumatology 1997; 1: $145-51$

13. Reyes L GA, Guibert T M, Hernandez M AA, Gonzalez O ZA, Alcocer V J, Cardiel MH. Prevalence of musculoskeletal complaints and disability in Cuba. A community based study
Burden of Rheumatic Diseases in A Rural Community of Bangladesh

using the COPCORD core questionnaire. Clin Exp Rheumatol 2000; 18(6): 739-742.

14. Drosos AA, Alamanos I, Voulgari PV, Psychos DN, Katsaraki A, Papadopoulos I et al. Epidemiology of adult rheumatoid arthritis in northwest Greece 1987-1995. J Rheumatol 1997; 24(11): 2129-33.

15. Kaipiainen- Seppanen O, Aho K, Isomaki H, Laakso M. Incidence of rheumatoid arthritis in Finland during 19801990. Ann Rheum Dis 1996; 55(9): 608-11.

16. Chan KW, Felson DT, Yood RA, Walker AM. Incidence of rheumatoid arthritis in central Massachusetts. AM. Arthritis Rheum 1993; 36(12): 1691-6.

17. Cardiel MH ; Rojas-Serrano J. Community based study to estimate prevalence, burden of illness and help seeking behavior in rheumatic diseases in Mexico City. A COPCORD study. Clin Exp Rheumatol. 2002; 20(5): 617-24.

18. Wolfe AM. The epidemiology of rheumatoid arthritis: a review. Bull Rheum Dis 1968; 23: 726-733.

19. Wigley R, Manahan L, Muirden KD, Caragay R, Pinfold B, Counchman $\mathrm{KG}$ et al. Rheumatic disease in Philippine village II: a WHO-ILAR-APLAR COPCORD study, phases II and III. Rheumatol Int 1991; 11: 157-61.

20. Stevens RJ, Mathews JA. A new protocol for low back pain. Practitioner 1997; 241:351-354.

21. Loza E, Abásolo L, Jover JA, Carmona L. Burden of disease across chronic diseases: a health survey that measured prevalence, function, and quality of life. J Rheumatol. 2008; 35(1):159-65.

22. Fautrel B, Guillemin F. Cost of illness studies in rheumatic diseases. Curr Opin Rheumatol 2002; 14(2): 121-6. 